\title{
¿Cuál sería su diagnóstico y su manejo terapéutico?
}

\section{What should the diagnosis and treatment be?}

\begin{abstract}
Mujer de 44 años que acudió a nuestra consulta presentando trismus severo de 4 meses de evolución después de exodoncia de cordal inferior izquierdo en otro centro, seguida de infección odontogénica. La apertura oral máxima era de $8 \mathrm{~mm}$. En la exploración física no se observaron procesos de infección activa, aunque sí dolor importante a la palpación de los músculos masetero y pterigoideo medial. La analítica sanguínea convencional no demostró ninguna alteración. El diagnóstico de presunción fue trismus secundario a infección odontogénica tras exodoncia y se estableció tratamiento a base de antiinflamatorios no esteroide-
\end{abstract}

os y miorrelajantes, sin mejoría tres meses después del diagnóstico inicial. Se decidió realizar tomografía computerizada (TC) cervicofacial, que no demostró alteración alguna. Con el diagnóstico de anquilosis fibrosa, la paciente fue sometida a cirugía bajo anestesia general e intubación nasotraqueal en la que se procedió a la apertura forzada de la cavidad oral y posterior colocación de abrebocas de goma para el mantenimiento de la apertura oral entre ambas arcadas dentarias derechas en la región de premolares y molares. La paciente permaneció 4 meses con el abrebocas, que se retiraba y recolocaba en las sucesivas exploraciones de seguimiento de la apertura oral conseguida. Después de este periodo, se objetivó una distancia interincisal estable de $35 \mathrm{~mm}$.

Un mes después la paciente acudió presentando una masa blanda indolora en el lado derecho del suelo de la boca, desde la región canina a la molar, adyacente a la cortical lingual mandibular. Se practicó excisión completa de la lesión incluyendo la glándula sublingual, con diagnóstico histológico de glándula salivar con infiltrados linfocíticos intersticiales e inflamación aguda y crónica periglandular. Se observó un epitelio estratificado normal sin atipia, con proliferación de estructuras vasculares con endotelio prominente en el tejido conjuntivo superficial, infiltrado de linfocitos, granulocitos eosinófilos y células fibroblásticas reactivas. Asimismo se objetivó la presencia de reacción histiocítica focal con células multinucleares gigantes de cuerpo extraño y material fibrinoide. El diagnóstico anatomopatológico inicial fue hiperplasia angiolinfoide con eosinofilia. Se realizó nueva intervención quirúrgica con resección de la lesión bajo anestesia general. A pesar del postoperatorio sin incidencias y sin recidiva de la lesión a nivel local, dos meses después la paciente acudió nuevamente a consulta presentando tres masas blandas de localización subcutánea submandibular derechas, con diámetros entre los 10 y $15 \mathrm{~mm}$ (Fig. 1). El nódulo de localización posterior presentaba fístulización cutánea con salida de material purulento. La citología por punción-aspiración con aguja fina informó de material abscesificado inespecífico.
A 44 year-old woman was seen for severe jaw stiffness of 4 months' duration after a lower left third molar extraction followed by odontogenic infection at another center. She could only open her mouth $8 \mathrm{~mm}$. No active infective processes were detected in the physical examination; palpation of the masseter and medial pterygoid muscles elicited intense pain. Conventional blood tests did not reveal any abnormality. Based on a presumptive diagnosis of trismus secondary to odontogenic infection, nonsteroid anti-inflammatory agents and muscle relaxants were prescribed. Three months after the initial diagnosis, the patient showed no improvement. Cervicofacial computed tomography (CT) did not disclose any alteration. The patient was diagnosed of fibrous ankylosis and underwent surgery with general anesthesia and nasotracheal intubation to force her oral cavity open and insert a rubber bite opener to maintain the opening between the right dental arches in the premolar and molar region. The patient continued with the bite opener for 4 months. The appliance was removed and replaced in successive follow-up examinations of the oral opening achieved. The stable interincisor distance achieved after this treatment was $35 \mathrm{~mm}$.

One month later, the patient was seen for a soft, painless mass of the right mouth floor, adjacent to the mandibular lingual cortical, that extended from the canine to the molar region. The lesion was excised completely with the sublingual gland. The histological diagnosis was interstitial lymphocytic infiltration of a salivary gland and periglandular acute and chronic inflammation. The epithelium exhibited normal stratification without atypia, with proliferation of vascular structures with prominent endothelium in the superficial connective tissue lymphocyte infiltrate, eosinophilic granulocytes, and reactive fibroblastic cells. A focal histiocytic reaction with foreign-body giant multinucleate cells and fibrinoid material was present. The initial pathology diagnosis was angiolymphoid hyperplasia with eosinophilia. In a new intervention, the lesion was resected under general anesthesia. Despite the absence of incidents or local recurrence in the postoperative period, two months after surgery the patient was seen again for three subcutaneous soft masses in the right submandibular region with diameters ranging from 10 to $15 \mathrm{~mm}$ (Fig. 1). The posterior nodule had fistulized to skin and secreted purulent material. Cytology of the fine needle aspiration biopsy material revealed nonspecific abscess-like material. 


\title{
Granuloma de cuerpo extraño en región submandibular. La migración de partículas de silicato de aluminio desde la mucosa oral
}

\author{
Submandibular foreign-body granuloma. Migration of aluminum silicate \\ particles from the oral mucosa
}

\author{
R. González-García', F.J. Rodríguez Campo², J. Sastre Pérez², V. Escorial Hernández², P.L. Martos', \\ M. Mancha de la Plata', M.F. Muñoz-Guerra², L. Naval-Gías²
}

Se realizó la biopsia de los nódulos, demostrándose una reacción linfohistiocítica con células multinucleadas gigantes de cuerpo extraño. Se objetivaron partículas birrefringentes oscuras-negras (Fig. 2). La mayoría de los linfocitos mostró inmunofenotipo CD8 positivo. Algunos de ellos mostraron positividad para CD4 con incremento de la fracción de crecimiento celular (Ki-67). Asimismo se objetivó la paulatina formación de nódulos de pequeño tamaño, de localización subcutánea e intradérmica, con pigmentación azul oscura y numerosas y pequeñas pústulas. El diagnóstico histológico fue granuloma de cuerpo extraño. La paciente negó cualquier aplicación local de productos cosméticos o inyección de substancias de relleno de tejidos blandos. Se realizó tratamiento médico a base de vibracina y cortisona a dosis de $60 \mathrm{mg} /$ día el primer mes, $30 \mathrm{mg} /$ día durante el mes y medio siguientes y $15 \mathrm{mg}$ los últimos 15 días, y excisión de las pequeñas formaciones nodulares de localización intradérmica y subcutánea mediante cirugía de desbridamiento local, con confirmación histológica del diagnóstico previo. No se objetivó recidiva de la lesión 6 meses después del tratamiento.

Varias muestras del material resecado a nivel submandibular y el abrebocas de goma fueron remitidas al Instituto Nacional de Toxicología y Ciencias Forenses, para el análisis de las inclusiones. Se emplearon diversas técnicas en el estudio, a saber: microscopia óptica, micro-espectrofotometría infrarroja con transformada de Fourier (FT-IR), y microscopia electrónica de barrido y energía dispersiva de rayos $X$ (SED-EDX). El análisis de los fragmentos obtenidos del abrebocas de goma mostró el espectro para silicona mediante FT-IR y silicio mediante SEM-EDX. De la arandela metálica del abrebocas se identificaron aluminio, hierro y níquel mediante SEM-EDX. La muestra PK del tejido resecado fue tratado mediante proteinasa K (Fig. 3). Se observaron espectros correspondientes con material glicoproteico y silicio mediante FT-IR, y silicio, azufre y alumino como componentes mayoritarios mediante SEM-EDX. Otros elementos como cal-

\footnotetext{
1 Médico Residente.

2 Médico Adjunto.

Servicio de Cirugía Oral y Maxilofacial.

Hospital Universitario La Princesa. Madrid, España
}

\section{Correspondencia:}

R. González-García

Hospital Universitario La Princesa

c/ Diego de León 62

28006 Madrid, España
Biopsy of the nodules demonstrated a lympho-histiocytic reaction with foreign body giant multinucleate cells. Darkblack birefringent particles were visible (Fig. 2). Most of the lymphocytes exhibited a positive CD8 immunophenotype. Some cells showed CD4 positivity with an increased cellular growth fraction (Ki-67). Gradual formation of small subcutaneous and intradermal nodules containing dark blue pigment and numerous small pustules was observed. The histological diagnosis was foreign-body granuloma. The patient denied any local application of cosmetic products or injection of soft tissue fillers. Medical treatment consisting of doxycycline and cortisone, in doses of $60 \mathrm{mg} /$ day the first month, $30 \mathrm{mg} /$ day during the following month and a half, and $15 \mathrm{mg} /$ day the last 15 days, was prescribed. The small nodular intradermal and subcutaneous formations were removed by local surgical debridement. The diagnosis of foreign body reaction was confirmed by histology. The lesion did not recur in the 6 months after treatment.

Several samples of the material resected in the submandibular region and the trismus appliance were sent to the National Institute of Toxicology and Forensic Science for analysis of the inclusions. Various study techniques were used: optical microscopy, infrared micro-spectrophotometry with Fourier's transformation (FT-IR), and scanning electron microscopy with energy-dispersive X-rays (SED-EDX). Analysis of the fragments from the trismus appliance revealed a silicone spectrum by FT-IR and silica by SEM-EDX. Aluminum, iron, and nickel from the metal washer of the trismus appliance were identified by SEM-EDX. The PK sample of resected tissue was treated with proteinase K (Fig. 3). Spectra of glycoproteic material and silica were obtained by FT-IR and silica, sulfur, and aluminum were the majority components obtained by SEM-EDX. Other elements, such as calcium, potassium, iron, sodium, chromium, and titanium, were isolated in smaller concentrations. The PKN sample of resected tissue was treated with proteinase K and nitric acid (Fig. 4). Spectra of aluminum silicate were observed by FT-IR. Silica and aluminum were isolated as the predominant elements by SEM-EDX. Other elements, such as iron, calcium, potassium and sodium, were identified in moderate con- 
cio, potasio, hierro, sodio, cromo y titanio fueron aislados en concentraciones menores. La muestra PKN del tejido resecado fue tratado mediante proteinasa $\mathrm{K}$ y ácido nítrico (Fig. 4). Se observaron espectros correspondientes con silicato de aluminio mediante FT-IR. Se aislaron silicio y alumino como elementos predominantes mediante SEM-EDX. Otros elementos como hierro, calcio, potasio y sodio fueron identificados en concentraciones moderadas, mientras que titanio, magnesio, sodio y bario fueron detectados en concentraciones muy pequeñas. Los resultados indicaron la presencia de silicato de aluminio en los tejidos examinados.

\section{Discusión}

La migración de partículas es un fenómeno referido raramente en relación con el tratamiento con productos inyectales de relleno de tejidos blandos, como silicona, hidrogel de poliacrilamida, ácido poli-L-láctico, Artecoll ${ }^{\circledR}$, ácido hialurónico, Dermalive ${ }^{\circledR}$, Gore-Tex ${ }^{\circledR}$ y otros. La migración de microesferas inyectadas ha sido estudiada previamente de modo experimental. De acuerdo con Lemperle et $\mathrm{al}_{,}{ }^{1}$ las microesferas de polimetilmetacrilato paracen ser las partículas más estables, mientras que el ácido poliláctico genera reacciones de cuerpo extraño, caracterizadas por el reclutamiento de macrófagos, células gigantes y algunas fibras elásticas. Característicamente, cuando los macrófagos han fagocitado un gran número de estas partículas (>10), a modo de células gigantes, son incapaces de moverse y migrar. En nuestra opinión, esta situación podría explicar la aparición de varios focos de reacción granulomatosa de cuerpo extraño a lo largo de una línea de migración concreta, como se objetivó en el caso presentado. Tres han sido los mecanismos implicados en la migración de partículas a lugares distantes: 1) vía hematógena, debido a la inyección accidental de una vena o vénula en el momento de la implantación, siendo los pulmones el punto de migración más frecuente; 2) vía linfática, debido a la lesión de grandes vasos linfáticos, los ganglios linfáticos locales, son el punto de migración más frecuente; 3) fagocitosis de partículas por macrófagos que viajan a través del sistema linfático a los ganglios linfáticos locales. Esta situación es extensible a las partículas alogénicas inyectadas en la región orofacial, en la que una tupida red de capilares linfáticos y vénulas drenan la mucosa oral y la piel de la cara. En estos casos, los ganglios linfáticos cervicales son el punto más frecuente de migración de las partículas. Se ha referido la aparición del fenómeno de migración de partículas en el momento de

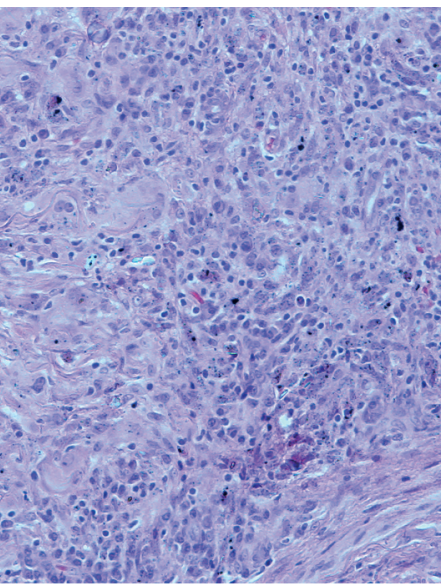

centrations, whereas titanium, magnesium, sodium and barium were detected in very small concentrations. The results indicated that aluminum silicate was present in the tissues examined.

\section{Discussion}

Particle migration is a phenomenon rarely reported in relation to treatment with injectable soft tissue fillers like silicone, polyacrylamide hydrogel, poly-L-lactic acid, Artecoll ${ }^{\circledR}$, hyaluronic acid, Dermalive $^{\circledR}$, Gore-Tex ${ }^{\circledR}$, and others. Injected microsphere migration has been studied experimentally. According to Lemper et al., 1 polymethylmetacrylate microspheres seem to be the most stable particles, whereas polylactic acid induces foreign body reactions that are characterized by the recruitment of macrophages, giant cells, and elastic fibers. Characteristically, when macrophages have phagocytized a large number of these particles (> 10) as giant cells, they cannot move and migrate. We believe that this mechanism may explain the appearance of several foci of foreign body granulomatous reaction along a specific line of migration, as observed in the present case. Three mechanisms are implicated in particle migration at a distance: 1) hematogenous pathway, due to accidental injection in a vein or venule at the time of implantation; the lungs are the most frequent destination of migration; 2) lymphatic pathway, due to injury of large lymphatic vessels; local lymph nodes are the most common migration destination; 3) phagocytosis of particles by macrophages traveling through the lymphatic system to local lymph nodes. These circumstances can be extrapolated to allogenic particles injected in the orofacial region, where a dense network of lymphatic capillaries and venules drain the oral mucosa and facial skin. In these cases, cervical lymph nodes are the most frequent destination of particle migration. The appearance of a particle migration phenomenon at the time of implantation and development of a fibrous capsule around the injected material have been reported. Nevertheless, the appearance of foreign body granulomas 
la implantación y antes del desarrollo de una cápsula fibrosa alrededor del material inyectado. Sin embargo, la aparición de granulomas de cuerpo extraño en lugares distantes varias semanas después del momento de la implantación, como en el caso presentado y en observaciones previas, ${ }^{1}$ aboga por la existencia de mecanismos complejos en la respuesta inmunológica del paciente. En cualquier caso, los mecanismos intrínsecos de formación y migración de granulomas de cuerpo extraño no han sido completamente aclarados.

Aunque varios autores han referido el fenómeno de migración de partículas tras la inyección de substancias alogénicas, la mayoría para el relleno de tejidos blandos, no existen referencias previas acerca de la migración de granulomas de cuerpo extraño a partir de partículas de polímero plástico no inyectadas. Durante el seguimiento de la paciente, se pueden establecer tres puntos fundamentales en relación con la localización y tiempo de aparición de las lesiones: 1) suelo de boca derecho, un mes después del tratamiento del trismus; 2) glándula sublingual derecha, tres meses después; y 3) región submandibular derecha, dos meses más tarde. Todas las lesiones presentaron una reacción histiocítica focal con células multinucleares gigantes, y material fibrinoide. Se demostraron partículas de coloración obscura a modo de cuerpo extraño en todas las lesiones. La paciente negó la inyección de substancias de relleno de tejidos blandos o la realización de procedimientos cosméticos en la región orofacial. Se estableció una relación directa entre el material de las partículas de cuerpo extraño encontradas en los focos de granuloma y la parafenilendiamina del dispositivo utilizado en el manejo del trismus durante 4 meses. Durante este periodo la fricción repetida de la superficie oclusal del dispositivo pudo provocar el desprendimiento de pequeñas partículas, que se depositarían en la región gingival y suelo de boca. A través de los canalículos salivares y/o ligamento periodontal de las piezas dentales adyacentes, un número indeterminado de partículas pudo acceder a la región submucosa. La posterior captación por parte de los macrófagos puede explicar el fenómeno de migración y la aparición de múltiples focos de granuloma de cuerpo extraño a lo largo del sistema de drenaje linfático hasta los ganglios linfáticos cervicales. La biopsia excisional de las masas en suelo de boca pudo alterar la integridad de las fascias musculares, facilitando la migración de partículas.

El diagnóstico diferencial de múltiples nódulos o inflamación cervico-orofacial persistente debe establecerse con varias entida- at a distance several weeks after implantation, as in the case presented and previous observations, ${ }^{1}$ supports the existence of complex immunological response mechanisms. In any case, the intrinsic mechanisms of foreign body granuloma formation and migration are not completely clear.

Several authors have reported the particle migration phenomenon after the injection of allogenic substances, generally soft tissue fillers, but there have been no previous reports of the migration of foreign body granulomas from plastic polymer particles that have not yet been injected. During patient follow-up, three fundamental points can be established with regard to the location and time of appearance of lesions: 1) right mouth floor one month after treating trismus; 2) right sublingual gland three months post-treatment; and 3) right submandibular region two months posttreatment. All lesions presented a focal histiocytic reaction with giant multinucleate cells and fibrinoid material. Dark colored foreign body particles were demonstrated in all lesions. The patient denied injecting soft tissue filler or undergoing cosmetic procedures in the orofacial region. A direct relation was established between the material of the foreign body particles found in granulomatous foci and the paraphenylendiamine of the appliance used to manage the patient's trismus during 4 months. During this period, repetitive friction on the occlusal surface of the trismus appliance could have caused small particles to separate and deposit in the gum region and mouth floor. Through the salivary canaliculi and/or periodontal ligament of the adjacent teeth, an indeterminate number of particles could have reached the submucosal region. Capture by macrophages may explain the migration phenomenon and appearance of multiple foreign-body granuloma foci throughout the lymphatic drainage system and cervical lymph nodes. The excisional biopsy of the masses on the mouth floor could have disturbed the integrity of muscular fasciae, thus facilitating particle migration. 
des, además del granuloma de cuerpo extraño. Algunas enfermedades inflamatorias pueden semejar esta presentación clínica, como la dermatitis de contacto, edema facial con eosinofilia, queilitis glandular apostematosa y síndrome de Ascher. Algunas enfermedades infecciosas pueden debutar con inflamación linfedematosa persistente, como la erisipela, tuberculosis, lepra lepromatosa, blastomicosis sudamericana y triquinosis. El amplio grupo de granulomatosis orofaciales debe ser considerado, y dentro del mismo la enfermedad de Crohn, el síndrome de Melkerson-Rosenthal y la sarcoidosis. La fibromatosis desmoide y el fibrosarcoma de bajo grado deben ser consideradas en casos agresivos y lesiones extensas. 3,4 Los hallazgos histológicos pueden malinterpretarse como hiperplasia angiolinfoide eosinófila, rara alteración benigna que debuta con nódulos intradérmicos o subcutáneos en la región de cabeza y cuello. Su aparición en la mucosa oral es, sin embargo, extremadamente infrecuente.

En relación con el tratamiento del granuloma de cuerpo extraño, se recomienda la resección quirúrgica para lesiones nodulares bien circunscritas. Para lesiones extensas, el tratamiento quirúrgico es controvertido. Algunos autores afirman que la erradicación del tejido granulomatoso es improbable, con formación de tejido cicatricial y fístulas. ${ }^{5}$ En nuestra opinión, la cirugía es la mejor opción también en estos casos, más aún si consideramos que el tratamiento corticosteroideo ha mostrado escasa o nula eficacia. Por supuesto, debe optarse por el abordaje quirúrgico menos agresivo que permita la exposición adecuada de la lesión, y considerar la opción reconstructiva en caso necesario.

En conclusión, la aparición de granulomas de cuerpo extraño puede atribuirse a la presencia de partículas de silicato de aluminio procedentes de dispositivos de rehabilitación de la apertura oral. El fenómeno de migración de estas partículas desde la mucosa oral hasta los ganglios linfáticos cervicales puede ser explicado por la fagocitosis de las mismas por parte de los macrófagos y su transporte a través de los vasos linfáticos en conjunción con procedimientos de desbridamiento quirúrgico a nivel local. El desarrollo de futuros estudios clínicos y experimentales permitirá clarificar numerosos aspectos fisiopatológicos en relación a la migración de partículas en el contexto de los granulomas de cuerpo extraño en la región orofacial.

\section{Bibliografía}

1. Lemperle G, Morhenn VB, Pestonjamasp V, Gallo RL. Migration studies and histology of injectable microspheres of different sizes in mice. Plast Reconstr Surg 2004;15:1380-90.

2. Dijkema SJ, van der Lei B, Kibbelaar RE. New-fill injections may induce late-onset foreign body granulomatous reaction. Plast Reconstr Surg 2005;15:76-8e.

3. Raszewski R, Guyuron B, Lash RH, et al. A severe fibrotic reaction after cosmetic liquid silicone injection. J Craniomaxillofac Surg 1990;18:225-8.

4. Peters E, Altini M, Dent M, Kola AH. Oral angiolymphoid hyperplasia with eosinophilia. Oral Surg 1986;61:73-9.

5. Ficarra G, Mosqueda-Taylor A, Carlos R. Silicone granuloma of the facial tissues: a report of seven cases. Oral Surg Oral Med Oral Pathol Oral Radiol Endod 2002;94: 65-73.
The differential diagnosis of multiple nodules or persistent cervico-orofacial inflammation includes several conditions aside from foreign-body granuloma. Some inflammatory diseases have a similar clinical presentation, such as contact dermatitis, facial edema with eosinophilia, cheilitis glandularis apostematosa, and Ascher's syndrome. Some infectious diseases may debut with persistent lymphedematous inflammation, such as erysipelas, tuberculosis, lepromatous leprosy, South American blastomycosis, and trichinosis. The broad group of orofacial granulomatoses must be considered, and within this group, Crohn's disease, Melkerson-Rosenthal syndrome, and sarcoidosis. Desmoid fibromatosis and low-grade fibrosarcoma must be considered in aggressive cases and extensive lesions. ${ }^{3,4}$ Histological findings may be misinterpreted as eosinophilic angiolymphoid hyperplasia, a rare benign disorder that debuts with intradermal or subcutaneous nodules in the head and neck region. Its appearance in the oral mucosa is, however, extremely uncommon.

The recommended treatment of foreign-body granuloma is surgical resection of well delimited nodular lesions. The surgical treatment of extensive lesions is debated. Some authors claim that the eradication of granulomatous tissue is unlikely and that scar tissue and fistulas will form..$^{5}$ In our opinion, surgery is also the best option in such cases, particularly if we consider that corticoid treatment has shown little or no effectiveness. The least aggressive surgical approach that allows adequate exposure of the lesion should be chosen. Reconstructive surgery should be considered as necessary.

In conclusion, foreign body granulomas may appear in the presence of aluminum silicate particles released by trismus rehabilitation devices. The phenomenon of particle migration from the oral mucosa to cervical lymph nodes can be explained by phagocytosis of the particles by macrophages and their transport through lymphatic vessels in conjunction with local surgical debridement procedures. Future clinical and experimental studies will make it possible to explain many pathophysiological aspects related with particle migration within the context of foreign body granulomas in the orofacial region. 